\title{
Rectal Emulsion Dosage Form
}

National Cancer Institute

\section{Source}

National Cancer Institute. Rectal Emulsion Dosage Form. NCI Thesaurus. Code C149883.

Liquid preparation consisting of an emulsion intended for rectal use or for diagnostic purposes. Rectal emulsions are usually presented in containers with a volume in the range of $2.5 \mathrm{~mL}$ to $2000 \mathrm{~mL}$. The container is fitted with an applicator or an applicator is provided separately. 